\title{
Understanding Kulayni`s mentality in Al-Kafi Structure Engineering
}

\section{Comprender la mentalidad del calor en la ingeniería de estructuras de Al-Kafi}

\author{
Sareh Bordbar" \\ Instructor in Maaref and Quran Knowledge University, Shiraz, Iran, Graduated from Ferdowsi \\ University of Mashhad, Mashhad, Iran \\ ORCID: https://orcid.org/0000-0002-8159-532X \\ Maryam Safari \\ BA Student in the Field of Maaref and Quran Knowledge in Maaref and Quran Knowledge \\ University, Shiraz, Iran \\ ORCID: https://orcid.org/0000-0003-4901-4297
}

Received 08-12-20 Revised 09-30-20

Accepted 10-13-20 On line 12-12-20

*Correspondence

Email: sbordbar@chmail.ir
Cite as:

Bordbar, S., \& Safari, M. (2021). Understanding Kulayni`s mentality in Al-Kafi Structure Engineering. Propósitos y Representaciones, 9 (SPE1), e815. Doi: http://dx.doi.org/10.20511/pyr2021.v9nSPE1.e815 


\section{Summary}

The precious work of Al-Kafi book has been studied and explored from various viewpoints, but the gap for lack of conducting study about structure of this work may be well perceived and analysis of various viewpoints of this arrangement is a task for which the necessity is felt to take it as a model in today world. In this valuable work, author has designated a specific system, but he has not mentioned it in its introduction. Hence, we try to analyze the engineering system taken by Kulayni (author) in structure of book of Al-Kafi. In order to achieve this objective, the arrangement of volumes of this book and related chapters and existing narratives in them along with the method used in their codification and regulation of chapters of this work has been investigated. The present research results in general system of this clerical encyclopedia i.e. relationship between this religious encyclopedia and order existing among the relevant chapters and Islamic traditions (Hadith) in them- based on the goal considered for writing of this group of volumes. Namely, author has selected ideologies, ethics and Islamic injunctions and tried to posit a comprehensive book based on what he has referred to it in prologue of this book. Kulayni has also considered specific technique in terminology of chapters by which he has actually indexed the related bibliography.

Keywords: Kulayni, Al-Kafi, Chapters of Al-Kafi.

\section{Resumen}

El precioso trabajo del libro de Al-Kafi ha sido estudiado y explorado desde varios puntos de vista, pero la brecha por la falta de estudios sobre la estructura de este trabajo puede ser bien percibida y el análisis de varios puntos de vista de este arreglo es una tarea para la cual es necesaria la necesidad. Sentí tomarlo como modelo en el mundo de hoy. En este valioso trabajo, el autor ha designado un sistema específico, pero no lo ha mencionado en su introducción. Por lo tanto, tratamos de analizar el sistema de ingeniería adoptado por Kulayni (autor) en la estructura del libro de Al-Kafi. Para lograr este objetivo, se ha investigado la disposición de los volúmenes de este libro y los capítulos relacionados y las narraciones existentes en ellos, junto con el método utilizado en su codificación y regulación de los capítulos de este trabajo. Los resultados de la presente investigación en el sistema general de esta enciclopedia clerical, es decir, la relación entre esta enciclopedia religiosa y el orden existente entre los capítulos relevantes y las tradiciones islámicas (Hadith) en ellos, en función del objetivo considerado para la escritura de este grupo de volúmenes. A saber, el autor seleccionó ideologías, ética y mandatos islámicos e intentó proponer un libro completo basado en lo que se refirió a él en el prólogo de este libro. Kulayni también ha considerado una técnica específica en la terminología de los capítulos mediante la cual ha indexado la bibliografía relacionada.

Palabras clave: Hoteles, Al-Kafi, Capítulos de Al-Kafi.

\section{Introduction}

The arrangement and codification of chapters is assumed as the important principles in any book in which the intent and purpose of author is sought. The order of chapters and structure of any volume of this book signifies knowledge of author of the given book. Book Al-Kafi is one of the four main Shiite Hadith books; therefore, it is vitally important to recognize various viewpoints of this book since it seems that the motive for writing of this book, taken by Kulayni, was not only collection and recording narratives within a single Hadith anthology.

Pondering on text of oration mentioned at the beginning of this significant work may show that the applicant demanded for a work that might comprise of all techniques of religious science so that anyone, who looked for religious science and related practice, based on proper 
effects and tradition of Ahl-Ul-Bait (PBHT), to be able to resort to this it. Referring to acceptance of request of applicant at the end of this oration, author expressed hope that his book might meet the requirements of Shiite community at his time and for the next generations in order to reach pure teachings of Ahl-Ul-Bait (PBHT) and for prevention from misleading.

Thus, this question should be proposed that how Kulayni managed to achieve this goal and for this reason it is doubly important to pay attention to Islamic traditions (Hadith) in this book and methods of collection and codification of chapters and writing of them.

To give answer to this question i.e. whether Master Kulayni has incorporated certain order in his work and posited regular geometry in it or not, several aspects of arrangement of the praiseful work will be explored and analyzed: 1) General order of encyclopedia (The relationship between various books and this encyclopedia as general), 2) Order between chapters of the book, 3) Relationship among narrative in any chapter, and 4) Method of terminology of chapters.

Searching in four given fields may lead us to this belief that Master Kulayni has written book of Al-Kafi using specific arrangement and for achieving the aforesaid goals in the prologue of the given book. In other words, author's statement was proposed to acquire the objective applicant of the book demanded for it and he has referred to them in introduction with respect to cultural climate governed over his time and the existing diversions. All parts of structure of this book have been designed according to a plan in which he has administered volumes, chapters and listed narratives in it to lead to the given purpose. Thus, it seems that logical and precise codification was implemented for chapters in book of Al-Kafi.

This study lacks independent background and it has been occasionally referred to arrangement chapters of Al-Kafi within the statements of great religious figures. It seems duly to look slightly and transiently at this trend to recognize author of this book and his work before entering the main topic.

\section{Identification of Author}

The salient religious encyclopedia of Al-Kafi is deemed as one of the oldest and most leading narrative Shiite books, which have been written by Abu Jafar Mohammad Ibn Isaac Kulayni AlRazi (329h/944AD-?), well-known as 'Seqat Al-Islam' (Islamic trustee jurist) and 'Raeis Al Mohadethin' (chief of Hadith-narrators) (Mirdamad, 1893:4, 38, 79, 107; Kashi, 6, 12, 165, 205, 217; \& Majlesi, vol. 106:159, vol. 107:36) during Minor Absence of $12^{\text {th }}$ Imam and it has been specially addressed by Shiite scholars and jurisprudents, who have cited from it in their important narrative references and valuable works for over eleven centuries. The reverent author of this book has spent many years for acquiring Hadith knowledge from the great masters in the fields of Islamic traditions in Rey, Qom and Baghdad. The attitude of great Shia scholars about Kulayni and his book is assumed as evidence for his unique scientific saliences within several centuries.

Najashi writes that the author was the Shiite Sheikh and Leader in Rey city and has cited Islamic traditions and narratives more than other scholars and was more trusted than all other jurists at his time (Najashi: 377, No 1026). Various stories have been narrated for praising of the late Kulayni by the scholars. (For these praiseful statements about Kulayni and his books, see also Toosi, vol. 4: 305, Al-Moshtabeh, Zahabi: 553; and Tabsir Al- Montabah be-Tahris AlMoshtabah, vol. 3: 1804; Mostafavi, Moqademah: 9; Khoei, 1970AD (1390h), vol. 1: 99; Mofid: 202; \& Agha Bozorg Tehrani, 17:245)

Seqat Al-Islam Kulayni was contemporary to four envoys and special agents of Imam Mahdi (AJ) and given he lived at the period of presence of Shia Imam (PBUT), he has narrated the Islamic traditions (Hadith) and news from the main sources (Amidi, pp. 75-76). 


\section{Recognition of Al-Kafi}

Book of Al-Kafi is one of Islamic narrative works written in $4^{\text {th }}$ hegira century $\left(10^{\text {th }}\right.$ AD century) including three parts of Islamic principles (Usul), minor injunctions (Foru) and anthology of narratives (Rozah) codified in 34 volumes of book, 862 chapters and 16234 narratives (Hadith) (according to counting by the Late Bahrani in book of Al-Lulu Al-Bahrain) among of which there are 5072 proper Hadith (Sahih), 144 reasonable Hadith (Hassan), 178 reliable Hadith (Movasaq), 302 strong Hadith (Qavi), and 9485 weak Hadith (Zaeif). (Toreihi, 193; Bahrani, 394-395)

Writing of Al-Kafi book was started when Kulayni (author) was the leader of Shiite people in Rey city; therefore, he enjoyed premium mastery and characteristics during arrangement for book of Al-Kafi.

\section{Engineering of Al-Kafi Structure}

In order to know whether Sheikh Kulayni has designated specific order in his book and proposed regular geometry in this work or not, we discuss about this subject from several dimensions:

1. General order of encyclopedia (relationship between different volumes of this encyclopedia as whole);

2. Order existing among chapters of any book volume;

3. Relevance between narratives in any chapter;

4. Terminological technique of chapters

Book of Al-Kafi has been discussed from four dimensions in the following and we scale it by analysis and research and propose the given outcome.

\section{General Order of Encyclopedia}

General order of Al-Kafi book is explored in this section; the order for which it necessitates observing throughout the book and the author has administered it to achieve the main objective for writing this book. However it is noteworthy to imply this point before starting main search that he has divided the sciences into two theoretical and practical categories in a general classification where this classification originates from two aspects of theoretical and practical wisdoms in human. Here wisdom means rational or more simply i.e. known. Theoretical wisdom denotes knowing about something if known it is assumed as perfection not to practice it. It is socalled: (what duly to be known). In other words, theoretical wisdom is what considered valuable to be known per se and it is (what observed in it).

While practical wisdom means knowing what deserved to be known not per se but to conduct it. In other words, this class of sciences is not valuable per se, but knowing them may precede their practice. Namely, they are (to what observed). Similar to ethical sciences in which only knowledge of moral issues is not assumed as perfection, but knowing them is valuable because it is an introduction to practice and conduct them (See also: Javadi Amoli, 2003: vol. 1: 122,142 ). Thus, knowledge includes two groups: (What duly to be known) and (What duly to be practiced).

We concern with Al-Kafi after knowing this point. Author of Al-Kafi has put epistemological topics at the first place; started from rationality and innocence and then discussed about knowledge and narrated some moral hadith after subjects of Unitarianism and Imamate and afterwards reached to minor injunctions (Ahkam). At the end, he has presented various groups of narratives within the section of 'Rozah' in Al-Kafi.

Thus by referring to salient encyclopedia of Al-Kafi and pondering in different volumes of this book, we may observe that the late Kulayni (His soul to be in rest) has addressed the aforesaid subject because he initially implied some narratives concerning the Islamic ideologies: 
Ideological Hadith have been classified in 8 volumes of books including: 'Al-aghl \& $\mathrm{Al}$ jahl' (Book of rationality and innocence), 'Al-fazl ol elm' (Book of virtue of knowledge), 'Attowhid' (Book of Unitarianism), 'Al-hojjah' (Book of reason), 'Al- Iman\& Al-kofr' (Book of faith and atheism), 'Al- do'a' (Book of praying), 'Al-fazl ol Quran' (Book of superiority of Quran), and 'Al-eshrah' (Book of ten).

Then narratives relating to practical field have been given, including two categories:

A: The Islamic narratives that are concerned with soul refinement and ethics and identifying ethical virtues and vices e.g. jealousy and haughtiness etc.

B: Those narratives that are exclusively related to the practice. Namely, juristic narratives implied in both categories are related to aspect of practical wisdom.

More simply, Sharia sciences are divided into three parts: Ideologies, ethics and injunctions in which the order preference of these issues is in that the ideologies are placed at the first rank since no one could invert to Islam- especially Shiism- without enjoying proper ideologies. Therefore it is obvious that primarily it necessitates for the subject i.e. the Muslim person to believe in proper ideologies as external realization and at the next step s/he should act based on the instructions that could provide salvation for him/ her both worlds. Whereas ethical science purports for expressing moral virtues and vices and their good and bad effects and method for assimilation to good habits and elimination of moral vices and then ideologies are put at the second place and prior to jurisprudence i.e. only as expression of Islamic injunctions. In fact, moral sciences include Sharia plan designated for nurturing of perfect humans and a method to make real human. Therefore, it is placed after ideologies and before injunctions.

Now we are familiarized with general arrangement of Al-Kafi, it will be marvelous to seek for answer to this question: Among all of important and various ideological issues, why this book has started with Islamic narratives about rationality and unsophistication? Kulayni implies rationality (wisdom) as a criterion for divine obligation, reward and torture in prologue of Al-Kafi and he has proved reasonability, validity, and legitimacy of wisdom, creation of wisdom, its nature and signs, blaming of innocence and corps of rationality and innocence etc.

It seems a delicate point lies in implication of these Hadith at the beginning of Al-Kafi under title of 'Book of rationality and unsophistication' that may confirm our claim about logical arrangement of this salient encyclopedia.

That point denotes that whereas wisdom perceives all of these subjects i.e. ideologies, ethics and injunctions; in other words, the correct beliefs can be distinguished from improper ones by wisdom and it is judged about presence of God, divine unity, prophecy of messengers of God and necessity for Imam and certainty of resurrection day by the aid of rationality. That is wisdom which perceives importance for assimilation to well morality and also by wisdom it is judged requisite for obeying from injunctions given by divine revelation and human may fail to perceive them lonely. Due to importance for position of wisdom and given that wisdom is the key for knowing ideologies, ethics and injunctions, Kulayni has consciously and properly implied these narratives at the outset of salient encyclopedia of Al-Kafi and thereby added to value of this encyclopedia.

The late Kulayni has referred to this point in some parts of the first oration of the book that there is a criterion in human's soul based on which the reward and punishment are determined for him/ her:

(Thus, wisdom is a pole anything rotates around its orbit and thereby reasoning is made and accordingly reward and punishment are determined). 
Moreover, it is implied in introduction that writing was made at the time when unsophistication and innocence predominated. One may find this point in complaining of applicant from the people who were accustomed to innocence. Author has assumed this point as an important reason to create misleading. Then in order to motivate readers to train these issues in this book, volume of 'book of virtue of knowledge' came after 'Book of rationality and sophistication' at the beginning of this encyclopedia thereby to create motive and enthusiasm in readers when start reading. It is because of this fact knowing something is deemed as requisite for doing of any activity. (Kulayni, 2008: 2/112, 7/117, 3/110, 2/109, 4/40, 1/108 and 1/86)

It is evident that Kulayni personally and briefly asserted in these two points:

(The first thing I start and open my book is the book of rationality and innocence and virtues of knowledge and high degree of knowledgeable people and their high position and defect of innocence and inferiority of innocent people and their lower position and wisdom is a pole anything rotates around its orbit and thereby reasoning is made and accordingly reward and punishment are determined). (Kulayni, 1987: vol. 1:9)

Author of book of Al-Kafi has presented a rational image of Shiite people by introducing wisdom as the criterion for obligation, reward and punishment in this book in addition to defending from legitimacy and validity of wisdom as a bounty deposited by God. Then given what mentioned in this introduction, he has introduced blind imitation from fathers and ancestors as one of the governing vulnerabilities while referred to position of knowledge seeker and knowledge seeking to identify religion- by focusing on pondering in the religion.

This section has deal with necessity for knowledge seeking, reward for trainer and trainee and characteristics of scholars. It seems author has noticed requisite for referral to experts after expressing characteristics of knowledgeable persons and has proposed the next chapter i.e. 'session with the scholars' and asking them that resulted in donation of knowledge.

While the scholar should be careful to avoid from heterodoxy and irrational analogy and refer other people to Quran and Islamic tradition in dealing with important issues and also should avoid from statement without adequate knowledge because it might result in heretical innovation in the religion. Therefore, the sections titled 'Al- rad ela ' 1 ketab \& al- sunna' (Refusal by Quran and Islamic tradition/ Sunna) and 'Nahi ane l' ghowl be ghaire elm' (Avoidance from statement without prior knowledge) are observed at the end of this chapter.

As it seen, Kulayni succeeded in establishing relation between chapters of any volume and also related narratives so that he managed to observe relations among them and whereas theology is the foremost science regarding improvement of individual and community, the next volume is 'Book of Unitarianism'. (Kulayni, 1988, vol. 1: 72)

1. Book of Unitarianism

The natural order of this topic may require primarily proving presence of Almighty God and then it is implied about His nature and essence and following to this trend it is discussed about names and attributes of Almighty God and related issues. As we can see in logic, the above-said phases have been assumed as necessary to identify objects (See also Commentary of book of Manzumeh, chapter of logic, Haji Sabzevari, 1990, vol. 1: 190, Al-Manteq (logic), Mozaffar, 2002: 101). As it seen, the late Kulayni has observed such an order and geometry. At the first chapter under title of 'Hoduth ol alam va ethbat ol mohdeth' (Emergence of universe and proving creator) (Ibid: 72), he has employed a rational reason as an evidence for emergence of the universe to prove existence of God and he narrated some Hadith from Imam Sadegh (PBUH) in this regard because any accidence required for a creator. Firstly, he mentioned principle of existence of God and then implied essence of Necessary Existent and permission for expressing it as an object. (Ibid: 82) Although he did not consider him separated from His essence, this issue might not contradict to what mentioned in philosophy under title of: Necessary Existent lacks certain essence (Tabatabaei, 2003, vol. 4: 165) that signified lack of certain essence for Almighty God 
because term of essence implied in philosophy meant limitation and possibility of an object with essence while the essence and object used in these narratives (Hadith) mentioned unlimited and glorifying nature of Almighty God. For example, he implied in the first Hadith that:

Mohammad Ibn Yaqub narrated from Ali Ibn Ibrahim from Mohammad Ibn Isa, from Abdul Rahman Ibn Abinajran who said that I asked Abajafar Imam Bagher (PBUH) about Unitarianism that I think about God in mind, is it God? He replied yes but He may not be embedded in human wisdom and He has no limits; God is other than what occurs in the mind; He is not similar to anything and the minds have not capacity to perceive Him. So, how minds could perceive His essence while He may not be perceived by minds. What perceived from God opposes to Him the same as what strikes in mind but human wisdom could not perceive it while He has no limit and end. (Kulayni, 1988, vol. 1: 82)

And also it was mentioned in Hadith VI as follows:

Someone asked: Thus God possesses existence and essence (nature is the same as essence) and Imam said: Yes. (Ibid, ' Etlagh el ghowle be annahu shaie' chapter of denoting Him as an object: 84 )

And in third chapter titled 'La yoa;raf ella be' (it is not known except by itself) (Ibid: 85), some of positive and negative attributes of God were mentioned. He also implied names and attributes of Almighty God including positive and negative attributes and qualities of essence and current qualities and their related topics such the least degree of cognition (under chapter of the least knowledge: Al-adna 1 maa'refa' (Ibid: 86)), number of names and attribute of Necessary Existent and contradiction of name and what nominated (under chapter of the worshiped 'Almaa'bud' (Ibid: 87)) and so forth in the next chapters.

However the fact is that Sheikh Kulayni implied several chapters about divine names and attributes. There are multiple narratives in this regard caused by variety of questions and issues mentioned in Islamic traditions and multiple answers given by Pure Imams (PBUT) where attributes of Almighty God have been addressed from certain viewpoint in each of them. Given the methodological disputes existing between Followers of Ahmad Ibn Hanbal (Hanabeleh), Asharite and Mutazilite sects etc. in this part, he has presented some narratives about rejection for observation of God, good and evil, salvation and affliction and so forth and finally he has related Unitarianism and reasoning by means of terminal chapters; hence, it necessitates for God to fulfill His reason and guiding His servants and wise people and it is not possible except by divine reasons. He presented this section as an introduction to enter next book called 'Al-hojja' (Book of reason). By reason he meant divine prophets and Pure Imams (PBUT).

\section{Book of reason (Al-hojja)}

He initially starts from some topics in book of reason e.g. principle of necessity for divine reason (titled chapter of necessity for the reason 'Al-ezterar el al hojja' (Kulayni, 1987, vol. 1: 168)) and their kinds (under title of chapter: Classes of prophets and God messengers and Imams or 'Tabaghat ol anbia \& rosol \& aemma' (Ibid: 174)) and difference between them (Called chapter of difference among prophet, messenger and Hadith- narrator: 'Al-fargh bain nabi \& rasul \& mohaddeth' (Ibid: 176)) and continues it with general subjects e.g. this paradigm that the earth planet will not exist without God's reason and messenger (titled chapter: 'Anna 1 arz la takhlu men al hojja', (Ibid: 178) and thereby he carries on expressing the subjects related to specific Imamate such as identification of Imam (under title of chapter of recognition of Imam and refusal against it: 'Al-maa'refa \& rad alayh', (Ibid: 180) and requisite for obeying from Imams (Chapter of necessity for obeying from Imams: 'Farz taate 1 aemma', (Ibid: 185) and Imams as witnesses to the people (Chapter of Imams as witnesses from the Glorifying God: 'Anna 1 aemma shohada Allah' (Ibid: 190) and Imams as guide for the people (Chapter denotes Imams are public guides: 'Anna aemah hom hoda' (Ibid: 191) and so forth. Of course the aforesaid topics may be also assumed as relating to general subjects in Book of Reason (Al-hojja), indexing of book of Sheikh 
Kulayni and the narrated traditions in these chapters suggested that he put these cases related to specific reason of God or at least as the distinct example for implied issues about them and specified them to Pure Imams.

Then he has explicitly discussed about Imamate of any Imam, ranging from title of implication and reference to Ali Ibn Abitaleb 'Al-eshara va an-nas ela ali ibn abitaleb' to implication and reference to owner of time 'Al-eshara \& al-nas ela sahib ed dar'. Those who have met that imam explained related subjects to him in chapters of description of one who saw him $\left(12^{\text {th }}\right.$ Shia Imam) (Ibid: 329), disappearance of $12^{\text {th }}$ Imam (Al-gheyba) and related chapter, prohibition from expression of his name under chapter of forbidding for expression of his name 'Al-nahy anel esm' (Ibid: 332) and duress for time of his appearance in chapter of timing duress 'Kerhia al-towghit' (Ibid: 338) etc. As it seen, Sheikh Kulayni (His soul rest in peace) has started expressing these subjects in book of reason (Al-hojja) and finished them with some details and examples. This is the appropriate method to express such topics so then he also proposed these issues proportional to historical chapters (Ibid: 439) which have been in fact as supplementary for Imamate and specific reason and events governed over the given period.

\section{Book of faith and atheism (Al-iman \& Al-kofr)}

He posits various phases of faith in God in book of faith and atheism after expression of an important part of ideologies at first volume of book of Unitarianism and reason and related subsidiaries including historical chapters to continue implication of ideological topics and them he starts from nature of human being and the related chapters. (In chapter titled nature of Godbeliever and atheist 'Tinat ol moa'men \& kafer' (Ibid: 2:2) and last chapter of this subject and additional part for occurrence of the former obligation (Ibid: 6 ))

Afterwards, he talks about world of pre-existence (Alam zar) (From the last chapter to chapter concerning quality of their answer and that is world of pre-existence: from 'Aakhr menh' to 'kayfa ajabu va hom zar' (Ibid: 12) and then he refers to human's nature that is related to creation of this corporal and elemental body (chapter concerning human's nature tending to Unitarianism: 'Al-fetra ala at-towhid' (Ibid:12), and then proposes presence of fetus of Godbeliever and atheist in the back of their ancestors. (Chapter on existence of God-believer in the fetus of atheist, 'Kown al-moa;men fi solb kafer' (Ibid: 13)). Later, he expresses method of genesis of God-believer (Chapter regarding when Almighty God intends to create a God-believer: (Ibid: 140)). For example, he says in this chapter:

It was narrated from Abi Abdullah (PBUH) that he said, there is tree in paradise called Al-Mozn when God wants to create a God-believer person, He pours a drop if reaches to vegetable or fruit, either God-believer or atheist eats it, Glorified God create a believer generation from him or her (Ibid: 14).

Then he expresses reality of faith in God (Chapter of enjoyment of Islam, 'Al-sebgha hya al-islam' (Ibid: 14)) and that is to resort to Firmest Handhold 'orvat ol vothgha' namely it is in fact to belief in those subjects have been mentioned in the first volume of this book. As Imam Sadegh (PBUH) expressed under the first and third Hadith, Firmest Handhold is the faith in united God who has no partner. He implies some of related phases of that fact i.e. divine relaxation and purity of conduct in the next chapter (Chapter concerning the fact that sense of serenity is the same as faith in God: 'Enna al-sakina (Ibid: 15)). In fact, chapter of Sharia rules 'Sharaea"' is the same supplementary for the preceding topics and he has mentioned dispersed narratives proportional to former issues.

As it visible, the late Kulayni follows different phases of human's existence in this book, ranging from time before creation of corporal body to intellectual virtues e.g. faith, purity of conduct and their relevant subsidiaries implied respectively in these chapters; namely, he has arranged chapters of the book based on existing order between human's existence phases.

Relevance between narratives in a chapter 
Al- Kafi is a book of Islamic traditions (Hadith); therefore, it should be mentioned that relevance existing between narratives in a chapter is subject to the common title selected by Sheikh Kulayni for the given chapter; in other words, in fact Kulayni express the subject by implying title of the given chapter and then mentions narratives concerning that subject under title of a single chapter. Now, some of chapters basically lack multiple narratives so that it is discussed about the given relevance and order among them e.g. chapter of rights of scientist 'Hagh ol aleme' (Kulayni, 2000, vol. 1: 105), chapter of difference of reason against His servants 'ekhtlaf ol hojja ala ebadeh' (Ibid: vol. 1: 469), chapter of subversion to females 'Al-taslim ala an-nesa' (Ibid: vol. 6: 519), chapter of rights of insiders 'Hagh al-dakhel' (Ibid: 555). Chapter concerning there is no dispute over permissibl 'la gheyra fi al-halal' (Kulayni, 1987, vol. 5: 537). In some cases, the narrative in the same chapter may express the single judgment about subject of given chapter so that it is impossible to assume a single arrangement between these narratives such as chapter of emergence of universe and proving of accidental world 'Hoduth ol alam va ethbat ol mohdeth' (Ibid: vol. 1: 211), chapter concerning implication of Him (God) as an object 'Etlagh al-ghowl be annah al-shaya'є' (Ibid: vol. 1: 239), chapter titled He (God) is not perceive except by Him 'Annah la yoa,raf ella beh' (Ibid, vol. 1: 249), chapter concerning the least knowledge 'Adna al-maa'refa' (Ibid: 251), chapter of the worshiped 'Al-maa,bud'n(Ibid: 253) and chapter regarding prohibition for discussion about quality of God 'nahy an al-kalam fi al-keyfiya' (Ibid: 269) etc. Although several contents were mentioned in narratives of these chapters, they implied the same judgment about subject of given chapter. However in some cases, the narratives may also express various injunctions and effects about subject of the chapter so that one could consider logical order between them. On these occasions, this order has been observed as well though finding of their relevance is a difficult task and needs a lot of care and thinking in some cases.

For instance, in chapter concerning necessity of knowledge and its acquisition and discussion about it 'Al-farz elm va vojub talabehi va hath alayh' (Ibid, vol. 1: 83), he initially implies some narratives that mention principle of requisite for knowledge and necessity for acquisition of science (Hadith I, II and III) followed by some narratives which encourage and induce to acquire knowledge. One may even understand from title of the chapter that Sheikh Kulayni has considered this order in implication of narrative in the given chapter.

The second example: Review on narratives in both chapters of divine serenity (Sakina) and purity of conduct (Ikhlas) (Kulayni, 1988, vol. 2: 15), he indicates in these hadith that divine serenity (Sakina) is faith in God and for this reason God sends down Sakina on hearts of Godbelievers- namely those who have already succeed to become God-believers- thus it is revealed this new faith is a level higher than former faith and also pure conduct (Ilkhlas)is also higher than this degree. As he expresses in the first Hadith:?

It was asked from Abi Abdullah Imam Sadegh (PBUH) about Quranic statement of Almighty God 'Hanif muslim'لم'Orthodox and Muslim' (Al Imran Sura 3:67), he replied that he (Abraham) was completely pure-conduct doer for God and there was no trace of idolatry in him (Kulayni, 1988, vol. 2:15).

Similarly, it is known from third Hadith and other traditions that:

Pure-conduct (Ikhlas) denotes a degree of faith in God where types of polytheism are removed from heart of God-believer even hidden polytheism and at this level person purely conducts for God (Mukhles).

In fact, Arabic term Ikhlas is an infinitive and denote nominal object in this chapter and in sixth Hadith of this chapter he refers to method of way-faring in this path i.e. seclusion and hermitic conduct with abstinence, insight and wisdom in heart and speech to it as the consequences. As he implies:

If a servant only remember Almighty God well for forty days, God will made him/her hermitic to the world and show him/ her world pain and cure and embed wisdom in his/ her heart and made his/ her tongue fluent to express it. (Ibid: vol. 2: 16) 
The natural order lies in a chapter is that firstly subject of chapter is mentioned and then definition and description is given about it followed by expression of related benefits and outcomes and finally it is implied about way of achieving of subject. Given different types of subject, of course, the implied contents may also vary, but in the events as narratives of chapter have potential for such an order, Sheikh Kulayni has observed this order. As it seen in this chapter, he primarily mentioned title of chapter and then dealt with definition of nature of pure conduct (Ikhlas) followed by expression of method to obtain pure conduct and its outcomes and this is a logical technique for codification of chapters.

Third example: He implies five Hadith in book of cleaning 'Al-tahara' in chapter of cleaning of water 'tahur ol maa" (Kulayni, 1988, vol. 3:1) in which he mentions general subject for cleaning nature of seas as whole in first three Hadith and then expresses one of water examples i.e. sea water in both fourth and fifth Hadith. (Ibid)

Fourth example: In chapter titled the water that does not become filthy by anything 'Almaa' allazi la yonajjesoh shay' (Ibid: 2)

Initially, he implies three narratives about general condition of Abundant Water (Kur) and expresses quantity and amount of abundant water. It is clearly evident that the general condition is prior to terms of their examples, quantities and amounts and the late Kulayni has observed this order preference for them.

Note:

In fact, the second stage for general division of this book starts after chapter of reality of faith and certainty (Kulayni, 1988, vol. 2; book of faith and atheism: 52) namely the phase in which the hadith narratives relating to practical wisdom or the same as ethics and he follow this subject from chapter of thinking 'Tafakkor' (Ibid: 54). He refers to identifying soul vices and virtues and way of removal of them i.e. praying and resorting to Quran and visit with people not seclusion from them. These cases are related to dimension of practical wisdom and this is proportional and relates these topics to former ones. Third part i.e. Hadith relating to injunctions also started from book of cleaning 'Al-tahara' (Ibid: vol. 3:1).

It is totally visible that Sheikh Kulayni (his soul rests bin peace) has observed relationship among totality of encyclopedia, its volumes and chapters as well as Hadith in any chapter.

\section{The given possibilities in order between narrative in any chapter}

Other possibilities have been also mentioned about way of arrangement and relevance between narratives in any chapter rather than what implied:

The first is that those Hadith, which are more clearly concerning subject of any chapter. Have been expressed at first place and in this way they are followed with clear narratives and then Succinct Hadith (Mojmal) are placed. (See also book of Aklil Al-Manhaj, Karbasi Khorasani, 2003: 284; Sean Chapter under title of Salim Ibn Ghays Helali, No. 473).

\section{Analysis}

This hypothesis (order preference based on clearness) can be accepted provided that narratives of chapter have mentioned identical contents and outcomes regarding the same subject; namely, narrative should have looked at the same subject from the identical point of view, but this possibility may not be proper if they have considered the same subject based on different perspectives.

In other words, they should express the same subject with different statements then we can see which of them is more obvious to imply it firstly and we may proceed in this way to reach a narrative, which has mentioned the same subject by a brief statement, while this is not the case, 
since the given narratives propose different contents in the same subject in most of chapters. For example, several narratives have been mentioned about subject of this chapter in the first volume of the encyclopedia i.e. book of rationality and innocence (Kulayni, 1988, vol. 1:10) in which despite their common subject they have no unity in content, but they express several issues and effects (e.g. investigation of wisdom, employing of wisdom by human, and difference among malice and wisdom etc.) for the given subject and it could not be necessarily concluded that sheikh Kulayni has expressed more obvious narrative firstly and at next step implied brief narratives.

A. The other possibility is that the order preference of narratives is based on accuracy of their document; namely, the narratives have been implied according to this order from the strongest, correct to the weak. (See also, book of Derayat Al-Hadith, Hosseini Jalali: 160).

Of course, this case is improbable because by looking at documents of narratives of AlKafi in salient book of Allameh Majelsi, this paradigm is rejected. For example we mention the status of document of narratives in a few chapters in Al-Kafi as follows:

Book of rationality and innocence 'Al-aghl \& al-jahl' : $1 \mathrm{~S}, 2 \mathrm{~W}, 3 \mathrm{P}, 4 \mathrm{R}, 5 \mathrm{R}, 6 \mathrm{~W}, 8 \mathrm{~W}$, $9 \mathrm{~W}, 10 \mathrm{~S}, 11 \mathrm{P}, 12 \mathrm{P}, 13 \mathrm{~W}, 14 \mathrm{~W}, 15 \mathrm{P}, 16 \mathrm{~W}, 127 \mathrm{~W}, 18 \mathrm{~W}, 19 \mathrm{U}, 20,21,22 \mathrm{~W}, 23 \mathrm{P}, 24 \mathrm{~W}$, 25, 26 W, 27 U, 28 P, 29 W, 30 P, 31 U, 32 R, 33 P, and 34 W. (Kulayni, 1988, vol. 1:10)

Book of virtue of knowledge, chapter of necessity of knowledge and requisite for its acquisition 'Ketab fazl ol elm \& bab farz elm va vojub talabeh:1, $2 \mathrm{U}, 3,4,5 \mathrm{P}, 6,7 \mathrm{~W}, 8 \mathrm{U}$ with strong potential, 9 W. (Kulayni, 1988, vol. 1:30)

Chapter concerning characteristic of scholar and his/ her superiority and virtue of scientists 'sefat ol alem va fazleh va fazl ol olama': 1, 2, $3 \mathrm{~W}, 4 \mathrm{P}, 5,6,7 \mathrm{~W}, 8 \mathrm{~S}, 9 \mathrm{U}$ or G. (Ibid: 32)

Chapter of groups of people 'Asnaf al-nas': 1 U, 2 W, 3 U, and 4 S. (Ibid: 33)

Book of reason, chapter of Urgency for reason 'Ketab al-hoja, bob izterar ela al-hojja': 1 $\mathrm{U}, 2 \mathrm{U}$ at strong level, $3 \mathrm{U}, 4 \mathrm{P}, 5 \mathrm{R}$ at strong level. (Ibid: 168)

Book of prayer, chapter times 'Ketab al-salah' bob mavaghit': $1 \mathrm{G}, 2 \mathrm{U}, 3,4 \mathrm{~S}, 5 \mathrm{G}, 6 \mathrm{~W}$, 7 S, 8 S, and 9 P. (Ibid: vol. 3: 273)

Given the aforesaid examples, it is clear such a claim could not be correct, but the strong and weak narratives have been mentioned regardless of considering any certain order among them.

B. Third possibility: The late Kulayni had no certain order-preference in mind for the given Hadith at any chapter, but he has gathered those correct narratives for him in any chapter under the same subject without specific arrangement. Although based on attitude of other scholars and by review of documents, incorrect narratives are also abundantly found in the book.

C. Other possibility: The narratives might be arranged in any chapter based on correctitude and weakness for order of evidences particularly given this fact that term of accuracy has different meaning for predecessors than the descendants because the preceding narrators assumed accompaniment of correctness evidence to the Hadith as criterion of accuracy i.e. system of evidences while the recent scholars considered documents analysis as the measure for correctitude or weakness of narratives. (See also book of Al-Kulayni and Al-Kafi, Sheikh Abdul Rasoul Al-Ghaffari, pp. 436-441). It is noted, on the one hand, that sheikh Kulayni claimed he has implied strong narratives; and on the other hand, according to attitude to the recent scholars all Hadith in Al-Kafi are not strong. Thus, given he was one of the preceding practitioners for quoting of Hadith, his criterion for accuracy of narrative is based on system of evidences that currently some part of them is missed and unknown for us. On the other hand, one of these evidences has been necessarily stronger than others in the same evidence system and it caused difference between Hadith in terms of strength and weakness. While it is possible for Sheikh 
Kulayni to imply narrated Hadith based on system of strongest evidences at first place and then mentioned those Hadith with lesser strength and potential based on system of evidences later respectively. With respect to content analysis of narratives in chapter and benefitting from science of philology of Hadith and reviewing them, this paradigm can be possible to some extent but it is beyond the scope of this paper.

It is noteworthy that this possibility differs from the former one in that those narratives he assumed them as strong in former possibility have been only collected regardless any certain arrangement between them, but according to this probability, the aforesaid arrangement has been considered between narratives in this chapter.

\section{Method of Terminology of Chapters by Kulayni}

In fact according to Sheikh Kulayni, titles of chapters are concerned with the subject derived from body of narratives in most cases sometimes without taking certain stance e.g. chapter of ability 'Istetaah' (Kulayni, 1988, vol. 1: 160), chapter of existence and place 'Kown \& makan' (Ibid: 88) and often with little orientation e.g. chapter of virtue of child 'Fazl ol valad' (Ibid: vol. 6: 2) and occasionally viewpoint of author is visible in title of chapter e.g. chapter concerning annulment of observation 'Fi ibtal royah' (Ibid, vol. 1: 95) and chapter regarding respect for old Muslim people 'Vojub ejlal fi shaybah al-moslem' (Ibid, vol. 2: 658) or chapter in disadvantage of laziness 'Kerahiah al-Kasal' (Ibid: 5:85) and sometimes he interprets them along with his own idea; for example, in chapter of testing and expertise 'Al-ebtela \& al-ekhtebar' (Ibid: vol. 1:152) as a title for one of the chapters. Term 'Ebtela' testing is found in the given Hadith but the late Kulayni has added term 'Ekhtebar' expertise and thereby he has revealed his interpretation for term 'Ebtela' testing and caused the audience to perceive term 'Ebtela' testing means 'Ekhtebar' expertise in this narrative according to his opinion.

As it implied, one could find attitudes of Kulayni from titles of chapters and mentioned narrative in them, but in some cases he expresses opinion under narratives of chapter. In this regard, you can see also the three following examples in which in one of them he implies his opinion about essential and practical attributes concerning essential attributes of God, another example is related to chapter regarding hermeneutics of Samad 'needless' as attribute of God (Ibid, vol. 1: 123) and also third case is concerned with chapter of Unitarian Communities 'Javamea, al-towhid' (Ibid: 134).

Given this introduction, referring to titles of chapters and their content may show that he has kept two aspects in mind for terminology of chapters:

- Use of titles shall be proportional to content of chapters in line with opinion of author.

- $\quad$ Employing terms existing in narrative of any chapter for their terminology in most cases so that many titles have been objectively implied in text of narratives e.g.:

* Chapter of nature of God-believer and atheist 'Tinah al-momeva al-kafer' (Fundamentals of Al-Kafi, vol. 4, book of faith and atheism: 15)

* Chapter concerning how they answered while in world of pore-existence 'Kayfa ajabu va hom zar' (Ibid: 43)

* Chapter of Islam before faith 'Islam ghabl al-iman' (Ibid: 91)

* Chapter regarding the faith is shared with Islam and Islam is not shared with faith 'Anna al-iman yashrak ol islam va al-islam la yashrak ol iman' (Ibid: 84 )

* Chapter denotes serenity 'Sakina' is the faith 'Anna al-sakinah hya al-islam' (Ibid: 51)

* Chapter concerning enjoyment is found in Islam 'Anna al-sebghah hya al-islam' (Ibid:

* Chapter denotes when God intends to create a believer 'Iza arada allah an yakhlogh almomem' (Ibid: 49) 
* Chapter denotes that God gives obligation only to one who likes Him 'Anna allah Ennama yoti ad-din man yohebboh ' (Ibid, vol. 4: 635)

He observes both dimensions as possible and it is very rare there is no deep content relationship among title of chapter and the related existing Hadith. For example, in chapter concerning reality of faith, title of chapter creates such an expectation to express those Hadith which denote reality of faith while he implies outcomes of faith in a few quoted narratives.

But now it may seem that the present method differs from that general technique; for example, he proposes the Islamic traditions relating to reality of faith in god under titles of chapters of enjoyment is the same as Islam, 'Al-sebgha hya al-islam'(Kulayni, 1988, vol. 1:14) and serenity is the same as faith and pure conduct (Ikhlas) i.e. 'Bob al-sakinah hya al-isam \& bob al-ikhlas'(Ibid:15) and so forth by the general method, but as it already implied, he selects reality of faith as a title for a chapter in which he expresses some of narrated anecdotes about effects of faith. In fact, such Hadith mention the way of achieving of faith and they are related to reality of faith, but they are not the same as reality of faith. However it should implied these two methods are not contradictory because method of codification of chapters and classification of an encyclopedia is not a practical technique and sheikh Kulayni has not manipulated the implied contents in these chapters in this respect, but terminological method is of overt type. More simply, given Al-Kafi book is a thematic encyclopedia, what a referent intends to acquire from this book is the ease of access to Islamic traditions where such an access requires for creation of an index that has been observed in codification of chapters while content of chapters and their relationship to each other is another subject the late Kulayni has followed it in practice.

Briefly, sheikh Kulayni take a practical method that is to arrange several books (ideologies, ethics and Islamic injunctions) and he has also followed a specific method for terminology of chapters. Probably one related dimension is that since Al-Kafi is an encyclopedia of Islamic traditions (Hadith) and he has been familiar with the used terms in this book and for the sake of ease of access to these Islamic narratives so the keyword has been selected for any chapter, one that is kept in minds of religious scholars (not any type of terms) and by this work he has presented an index for terms.

In fact, this terminological method is a type of presentation of thematic index about the existing Hadith in that chapter. Take for example, someone looks for Islamic traditions in which term of 'reality of faith' has been implied; thus, s/he can easily find them by referring to titles of chapters. The point is here that Kulayni selects a title from body of Hadith on which the main topic of given Hadith is based. Therefore, such titles are a type of indexing as well, in fact.

\section{Conclusion}

It is concluded that the method taken by Sheikh Kulayni in structure of Al-Kafi book possess stable logic and he has observed his method within general order of this encyclopedia and chapters and Hadith of any volumes as possible. In prologue of Al-Kafi, Kulayni expresses wisdom as the criterion for divine obligation, reward and punishment and deals with proving legitimacy, validity, legality of wisdom, genesis and quality and signs of wisdom, blaming of innocence, and rationality and innocence corps etc. in this book. Whereas wisdom is the agent for perception of these issues i.e. ideologies, ethics and Islamic injunctions and the issues including the existence of God, unity of creator, prophecy of messengers of God and necessity for Imam and certainty of resurrection day can be proved by the aid of wisdom. Due to importance for position of wisdom and this fact wisdom serves as key for identifying of ideologies, ethics and Islamic injunctions, he has consciously and properly mentioned these Hadith at the beginning of salient encyclopedia of Al-Kafi and thereby added to value of this encyclopedia. Kulayni has succeeded to establish relationship between chapters of any volume as well as narratives of this chapter so that he managed to observe relationship among them and whereas theology is deemed as the foremost 
science concerning improvement of individual and community thus it has been implied after books of 'rationality and innocence' and 'Unitarianism'. In this book, the late Kulayni follows various phases of human existence, ranging from before genesis of corporal body to intellectual virtues including faith in God and pure conduct and their related subsidiaries in these chapters respectively; namely, he has arranged chapters of this book respectively based on existence phases of human. The natural order of a chapter lies in this fact that primarily the subject has been proposed and then some definition is presented about the subject followed by implication of given benefits and outcomes and finally the method of achievement of this objective is mentioned. Of course, with respect to variety of subjects, the mentioned issues may also vary; however, in some events when the narratives of chapter have potential for such an order, sheikh Kulayni has observed such an order. As it seen in chapter of pure conduct (Ikhlas), he has implied this subject as title of chapter where after definition of pure conduct and then reality of it then he mentions way of obtaining pure conduct with the related outcomes. This is a logical method for codification of chapter. There are some possibilities in arrangement of Hadith so that it very unlikely for sheikh Kulayni to mention Islamic traditions primarily with respect to strongest evidences and then he implied less strong Hadith respectively based on system of evidences later. Sheikh Kulayni also takes a practical technique for terminology of chapters i.e. arrangement of books (ideologies, ethics and Islamic injunctions) and he has followed his specific method for terminology of chapters as well. Since Al-Kafi is an encyclopedia of Hadith the clerical scholars, who are familiarized with Islamic tradition texts and used terms in Hadith, may concern with it therefore in order to have ease of access to Hadith, the keywords have been selected for any chapter, ones kept in minds of scholars (not otherwise) and thereby he has posited a thematic index.

\section{References}

Agha Bozorg Tehrani, Mohammad Hassan. (1403h/1984). Al-Zaria, nameless: Beirut.

Asghalani, Ibn Hojr (?). Tabsir Al-Montabah Be-Tahris Al-Moshtabah. Beirut: Scinetific Library.

Bahr Al-Ulum, Mohammad Mehdi Ibn Morteza. (1385-1386h/1966-1967). Al-Rejal (known as Favayed Al-Rejaliyeh), Libraries of two scholars: Al-Toosi \& Bahr-Al-Ulum: Najaf.

Bahrani, Yusef Ibn Ahmad. (?). Lu-Lu Al-Bahrain Fi Al-Ejazat Va Trajem Rejal Al-Hadith, Najaf: Al-Noman Pub.

Gjaffari, Al-Sheikh Abdul Rasoul. (1416h/1995). Al-Kulayni Va-Al-Kafi. Qom: Islamic publication institute (affiliate to Qom Seminary Instructors' Community).

Hojat. Hadi. (2007). Shia Hadith communities. Tehran: Organization for study \& Publication of humanities books of academies (SAMT).

Javadi Amoli, Abdullah. (2003). Rahiq Makhtum (commentary of transcendental wisdom). Qom: Esra Press.

Kashi, Mohammad Ibn Umar (?). Rejal, Qom: Al-Ul-Bayt (PBUT) Institute.

Khoei, Seyed Abolghasem. (1390h/1970). Mojam Rejal Al-Hadith (Glossary of Hadith narrators). Najaf: Al-Adab Pub.

Khorasani Karbasi, Mohammad Jafar Ibn Mohammad Taher. (2003). Aklil Al-Manhaj Fi Tahghigh Al-Matlab, by Seyed Jafar Hosseini Eshkevari, Qom: Hadith Institute.

Kulayni, Mohammad Ibn Yaqub. (?). Usul Kafi (Fundamentals of Al-Kafi), Transl. Seyed Javad Mostafavi. Tehran: Islamic Scientific Institute.

Kulayni, Mohammad Ibn Yaqub. (1394h/1974). Meraat Al-Uqul Fi Sharh Akhbar Al-Rasoul (PBUH). By Mohammad Bagher Ibn Mohammad Taghi Majlesi, Tehran: Islamic Books Institute.

Kulayni, Mohammad Ibn Yaqub. (1407h/1986). Al-Kafi (8 volumes). Tehran: Islamic books institute.

Kulayni, Mohammad Ibn Yaqub. (1429h/2009). Al-Kafi. Qom: Hadith Institute.

Kulayni, Mohammad Ibn Yaqub. (2000). Usul Kafi (Fundamentals of Al-Kafi), Transl. Mohammad Bagher Kamarehi. Tehran Osveh Pub (affiliate to Endowments \& Charities Organization). 
Maaref, Majid. (1998). General history of Hadith. Tehran: Kavir Pub.

Majlesi, Mohammad Bagher Ibn Mohammad Taghi. (1403h/1984). Bahar Al-Anvar. Beirut: Arabic heritage revival institute.

Mirdamad, Mohammad Bagher Ibn Mohammad. (1311h/1894) Al-Ravasheh Al-Samaviyah FiSharh Al-Ahadith Al-Emamiyeh. Qom: Caliphate Pub.

Mofid, Mohammad Ibn Mohammad. (1984). Tashih Al-Eteghad Be-Savab Al-Enteghad. Qom: Al-Sharif Al-Razi Press.

Mozaffar, Mohammad Reza. (2003). Al-Manteq (logic). Qom: Publication office of Science institute.

Sabzevari, Molla Hadi. (1990). Commentary of Manzumeh (Al-Leali Al-Montazemah). Tehran: Nab Pub.

Sadreddin Shirazi, Mohammad Ibn Ibrahim. (1366h/1946), Commentary of Usul Al-Kafi, Transl. Mohammad Khajavi, Tehran Cultural Studies \& Researches Institute.

Tabatabaei, Mohammad Hossein. (2000). Shia in Islam. Qom: Press office of Islamic Publication (affiliate to community of instructors of Qom Seminary).

Tabatabaei, Mohammad Hossein. (2003). Nahayat Al-Hekmat, Qom: Publication center of Imam Khomeini (RAH) Eeducational \& Research Institute.

Toosi, Abijafar Mohammad Ibn Hassan. (1972). Al-Fehrest, Edited by Mahmud Ramyar. Mashhad: University of Mashhad.

Toosi, Mohammad Ibn Hassan. (1390h/ 1970). Al-Estebsar Fima Ekhtolefa Men-Al-Akhbar. Tehran: Islamic Books Institute.

Toreihi, Fakhreddin Ibn Mohammad. (1374h/1954). Jame Al-Maqal Fima Yataalaq Be-Ahval AlHadith Va-Al-Rejal, Tehran: bookshop of Jafari Tabrizi.

Zahabi, Shamseddin. (?). Al-Moshtabah. 